\title{
Refiguring Difference: Imaginative Geographies and "Connective Dissonance" in Three Novels of the Iraq War
}

\section{Daniel O’Gorman}

This article analyzes three contemporary novels that engage with the most recent Iraq war: Point Omega by Don DeLillo (2010), Gods Without Men by Hari Kunzru (2011) and The Yellow Birds by Kevin Powers (2012). I argue that the novels work to redress what Judith Butler has described as a dehumanizing "derealization of loss" - or "insensitivity to human suffering and death" - in the context of Western media representations of the war on terror (Precarious 148). According to Butler, this derealization "takes place neither inside nor outside the image, but through the very framing by which the image is contained" (148). She refers to the US "shock and awe" bombing campaign over Baghdad in 2003 as an example of how the framing of the war often "numbs the senses," and "puts out of play the very capacity to think" (148). More importantly, she adds that "[t]his production takes place not only for the Iraqi population on the ground, whose senses are supposed to be done in by the spectacle, but also for the consumers of war who rely on CNN or Fox" (148). The "derealization of loss" is, in other words, a consequence of a broader derealization of Iraq itself: the "shock and awe" of the war's framing in the media effectively works to occlude the nation - and, in turn, its people - from view.

I suggest that the three novels in question challenge this "derealization" of Iraq by attempting to shift what geographer Derek Gregory (following Edward Said) might describe as their readers" "imaginative geographies": that is, the frames of perception through which "[we] articulate not simply the differences between this place and that, inscribing different images of here and there, but ... [that] also shape the ways in which, from our particular perspectives, we conceive of the connections and separations between them" (Geographical 
204). Specifically, I aim to demonstrate how Point Omega, The Yellow Birds and Gods

Without Men produce what Gregory, building on this idea, has more recently characterized as the potential for a desirable post-9/11 "connective dissonance," or the creation of new empathic ties between Americans and Iraqis not despite their differences but because of them (Colonial 256).

\section{Difference and Dissonance}

In The Colonial Present: Afghanistan, Palestine, Iraq (2004), Gregory critiques what he sees as the Bush administration's appropriation of 9/11 for a destructive neo-imperial agenda that relies upon a reactionary reinforcement of a narrowly delineated Western "self." He writes that " $[\mathrm{t}]$ he ordinary dead came from every corner and culture," and argues that this diversity “destabilizes the Manichean assumptions that divide the world tidily into 'us' and "them"” (69). However, he suggests that this deconstruction of "us" and "them" should not occur simply through an emphasis on "spacings of connection" (such as "transnational capital circuits and commodity chains, ... global flows of information and images, ... geopolitical alignments and military dispositions"): he posits that it might also be achieved through a focus on "spacings of disjuncture between the same and the other" (255). These spacings, he suggests,

are installed through the same or parallel economic, cultural, and political networks but articulated by countervailing imaginative geographies that give them different force and sanction. Imaginative geographies are thus doubled spaces of articulation. Their inconsistent topologies are mappings of connective dissonance in which connections are elaborated in some registers even as they are disavowed in others. (255-6) 
Gregory draws on this idea of a "connective dissonance" through imaginative geographies in an explicitly political way, condemning the 2003 invasion of Iraq on similar terms as he did the first Gulf War in his influential 1994 study, Geographical Imaginations. ${ }^{1}$

In contrast to Gregory, I am not concerned here with rehearsing a case either for or against the invasion of Iraq in 2003. Instead, I wish to draw upon Gregory’s notion of "connective dissonance" in a way that similarly challenges the divisive "us and them" identity structures perpetuated in global media discourse about the war. I suggest that the three novels in question utilize geographical location in a way that foregrounds its topological "inconsistency"; that is, the unstable attribution of meaning - or identity - to a location through culture and political discourse. In turn, each text encourages its reader to make a connection between this inconsistent mapping of geography and the similarly inconsistent way in which the characters in the novels map each other's identities (and allow identities to be mapped onto themselves).

It is because of this inconsistency in the mapping of identity that, following Gregory, I use the term "connective dissonance" as opposed to "connective difference." While, as I aim to show, the novels in question do sometimes encourage connections between apparently incommensurable identities through a shared experience of difference, the use of the term "dissonance" here specifically pertains to the shifting, amorphous and literally inconsistent relationship between sign and signified: it indicates an ambiguous space between identities in much the same way as a dissonant musical chord occupies an ambiguous space between notes. When Gregory writes that "connections are elaborated in some registers even as they are disavowed in others," I take him to be referring to the way in which a single signifier might invoke a variety of contrasting and even conflicting meanings, depending on the perspective from which one approaches it. It is this dissonance inherent to the process of identity 
construction that, I argue, the three Iraq war novels foreground in a way that builds connections between radically different post-9/11 identities.

The article will be divided into two main sections. In the first, "The Wilderness: Imaginative Geographies and the 'derealization of loss,'” I analyze the novels' locational reliance upon deserts, hinterlands and backcountries. I suggest that they use these wilderness landscapes, and their deep-seated connections with national cultures and identities, to help reshape the "imaginative geographies" through which their readers frame an understanding of the world. This is one way in which they help to redress the "derealization of loss" that Butler identifies as the "mechanism," in mainstream framings of the war on terror, "through which dehumanization is accomplished" (148). In the second section, "Absence and 'Grievability,"” I narrow my focus to a specific characteristic of the wilderness, suggesting that each novel uses the wilderness to explore the boundary between absence and presence. In doing so, they figure the absence of recognisably "grievable" Iraqi lives in global representations of the war as a haunting presence, thus complicating the media-driven categorization of global identity in reductive binary terms.

\section{The Wilderness: Imaginative Geographies and the "derealization of loss"}

The US backcountry has provided DeLillo, Kunzru and Powers with a fruitful trope through which to explore some of the challenges posed to American identity since the launch of Operation Iraqi Freedom in 2003. All three articulate a desire in their novels to think about American identity in a transnational way: not only do they underscore the multiplicity of identities contained within the nation, but they also, in turn, draw attention to its place in a global, inter-relational constellation of world identities. They do this, I suggest, through a 
depiction of troubled metropolitan characters experiencing crises in the American wilderness, a landscape characterized as much by its "vast emptiness" as by its abounding cultural history. What this rethinking of American identity ultimately entails is akin to what Richard Gray has described in After the Fall: American Literature Since $9 / 11$ as the often unfulfilled potential for post-9/11 literature to "enact difference": that is, to provide "not only the capacity to recognize that some kind of alteration of imaginative structures is required to register the contemporary crisis, ... but also the ability and willingness imaginatively to act on that recognition" (30). Through their representations of the Iraq war and its aftermath, the novels use the wilderness as a tool through which to help bring such an "alteration of imaginative structures" about. In turn, they help redress the kind of "derealization of loss" that, in Butler's view, has resulted from an imbalanced framing of violence in the context of the war on terror $(148)$.

\section{“[M]odernity and its Discontents": The Wilderness and Identity}

From slavery and the Civil War through to Twentieth Century cinema, the idea of the wilderness - and particularly its "taming" (or, perhaps more often, its resistance to taming) has been deeply embedded in discourses of American identity. After the Second World War, holiday trips into the wilderness soared in popularity amongst Americans to the point where the land's natural beauty began to be damaged by the volume of cars and caravans that were passing through it, and in 1964 the United States Wilderness Act was passed. The Act states that "wilderness, in contrast with those areas where man and his works dominate the landscape, is hereby recognised as an area where the earth and its community of life are untrammelled by man, where man himself is a visitor who does not remain" (Lewis 4-5). 
However, as Michael Lewis argues in his edited collection American Wilderness: A New History:

Though crucial to U.S. identity and history, the wilderness idea has never been just an American idea. Rather, it was derived from the shared human experience of modernity - the initially Euro-American, then global, experiences of the scientific revolution, exploration, colonialism, industrialization, and the dramatic transformation of the natural world. (12)

He goes on to suggest that:

U.S. historians have been convinced that to understand American wilderness is to understand a crucial part of America. Perhaps they have undersold the importance of wilderness history; perhaps to understand wilderness is to understand part of the more global history of modernity and its discontents: our values, our hopes, our blind spots, and our fears, overlaid on a rapidly changing planet. (12)

The US wilderness, in other words, is a quintessential element of American identity, but also one that transcends the limits of identity, connecting the nation's history to the broader historical context of global modernity.

All three of the Iraq war novels that I am analysing in this chapter use the wilderness as a trope through which to do something very similar, utilizing its place at the heart of American cultural tradition to subtly decentre their readers' understanding of this identity, and in turn placing it in a more globally interconnected context. Kunzru's Gods Without Men does this most explicitly. The novel has multiple narratives that take place at different points in American history, but that are connected through a shared setting: the vast Californian desert surrounding a mysterious three-spired rock formation known as "The Pinnacles." (The book's title is a direct reference to the closing lines of Balzac's short story, "A Passion in the Desert": “"In the desert, you see, there is everything and nothing ... it is God without mankind"' [327].) One of the narrative segments, set in 2008, focuses on an Iraqi teenage girl called Laila, a refugee of the current conflict who - along with her brother, Samir, and her uncle, Hafiz - takes part in a US military training program in which a part of the desert near 
the Pinnacles is transformed into a highly realistic simulation of an Iraqi town called "Wadi al-Hamam." (The name is likely to be an ironic reference to the Palestinian town of the same name, which was destroyed during the establishment of Israel in 1948 [Khalidi, 544-5].) The notion of an "untrammelled" wilderness is totally undercut by the artificial town, and through it a connection is immediately made between America's past and present colonial histories: by placing the town in the location that he has, Kunzru evokes the memory of its annihilated Native communities at the same time as he satirises the "counter-insurgency" tactics of the US military during its contemporary nation-building efforts in Iraq.

Kunzru has made it clear in interviews that the Mojave Desert has an intimate personal connection for him with 9/11:

I got stuck in Los Angeles on 9/11. I'd been in California for a couple months and was supposed to fly home to England the next day, which was not going to happen. ... People were losing their minds. I decided to get out of the city and drove to Death Valley, which seemed quiet and appropriate. I had a very intense few days. It stayed with me, but I didn't realize I had to write about it until much more recently, in 2008. (Kumar n. pag.)

However, despite the author's strong sense of connection to the location, I would suggest that the backdrop of the American desert helps to deterritorialize the location's cultural connotations. It does this by driving home the difficulty for those whose perspective on the war is framed by global news channels to viscerally empathise with the experiences of ordinary Iraqis during the fighting. This is not to say that Kunzru straightforwardly transplants the Baudrillardian argument that the "Gulf War did not take place" into the present Iraq conflict (1995). On the contrary, he acknowledges developments in news reportage since the first Gulf War by having the training programme include a very contemporary, "reality"-style fake TV channel called "al-Mojave," whose reporters "would sometimes show up and interview the villagers about how pro-American they were feeling" $(300-1)$. 
The impact of this derealization is underscored at the chapter's conclusion. When Laila is playing with a pair of night-vision goggles that she has borrowed from one of the marines, she spots an unusual figure "[o]ut in the emptiness, away from town" (308). Unsure what it is, she thinks: "This was how she looked to the soldiers, a little point of thermal light, a grid reference to be targeted with a bomb or a drone or a shot from a sniper rifle" (308). In this scene the "imaginative geography" of the Californian desert is briefly disentwined from American cultural history, and becomes uncannily interchangeable with the desert terrain of Iraq. The "little point of thermal light" turns out to be the missing child of the novel's protagonists, an estranged married couple who have been searching frantically for their son since mysteriously losing him in the desert. However, in the disorientating moments before this is made clear, the signification of the American desert is briefly uprooted and reconnected to a more global constellation of signs.

\section{"[A]nother desert altogether": Manipulating Realities}

A similar "connective dissonance" is evident in the representation of the wilderness in DeLillo's Point Omega. Like Gods Without Men, the novel is concerned (among other things) with a 'derealization of loss' in the framing of the Iraq War, this time in US politics. The novel follows a young filmmaker's attempt to interview a retired US military advisor - or "defense intellectual" - called Richard Elster, who was called upon to help conceptualize the "intellectual framework" for troop deployment in Iraq (28). He is, in a sense, the closest that any of the three novels come to a direct characterisation of the hegemonic power behind the framing of the war (Butler describes the framing process as one of "selectively carving up experience as essential to the conduct of war" [23]). While at first reluctant, Elster agrees to the interview on the condition that it take place at an old, isolated house that he owns 
"somewhere south of nowhere in the Sonoran Desert or maybe it was the Mojave Desert or another desert altogether" (20).

Like in Kunzru's novel, the landscape's "inconsistent topology" here is partly due to its "vast emptiness" and general absence of human occupancy: "There was the house and then nothing but distances," DeLillo writes, "not vistas or sweeping sightlines but only distances" (18). It helps provide the groundwork - both literally and figuratively - for the introduction of a degree of connective dissonance to Elster's intentionally reductive "framing" of Iraq in the lead-up to the invasion. "There were times when no map existed to match the reality we were trying to create," Elster explains. He continues:

We were devising entities beyond the agreed-upon limits of recognition or interpretation. Lying is necessary. The state has to lie. There is no lie in war or in preparation for war that can't be defended. We went beyond this. We tried to create new realities overnight, careful sets of words that resemble advertising slogans in memorability and repeatability. These were words that would yield pictures eventually and then become three-dimensional. (28-9)

Commenting on this passage, Richard Gray has suggested that it draws attention to a "strange dematerialization of the material" in the way that the war was conceptualised by people like Elster. However, rather than attempting to "rematerialize" the material, so to speak, DeLillo gestures toward a need to imagine a new, albeit no less immaterial reality into being: one that encourages empathic global connections rather than cynically downplaying them, as Elster's does. Like in Gods Without Men, DeLillo does this by having Elster lose a child in the wilderness. Shortly after his daughter unexpectedly comes to stay with him at the house, she suddenly and inexplicably goes missing. Suicide, abduction and murder are all raised as possibilities, but nothing is ever confirmed. Elster has contributed to a "derealization of loss" in the lead-up to the Iraq War, but when he loses his own daughter, he is forced to experience the "local grief" of such an experience first-hand (98). "The story was here," the narrator says, "not in Iraq or in Washington, and we were leaving it behind and taking it with us, both" (99). 
As John Banville puts it in a piece on the novel in the New York Review of Books, the reader ultimately becomes aware that "[t]he weighty teleological speculations that Elster indulges in ... are as light as the dust of the desert, Californian or Iraqi, in comparison with the life, and the loss, of one frail, damaged human creature" (“Against" n. pag.).

\section{Misguided Archaeologies and Particular Histories}

A kind of "local grief" also haunts Kevin Powers' The Yellow Birds. Powers served in Iraq with the US Army in 2004 and 2005, but the story he tells is a fictional one, following the repeated attempts of a soldier called John Bartle to come to terms with the brutal killing and mutilation of his friend, "Murph," by Iraqi militants. Bartle's name is almost certainly a reference to Melville's short story, "Bartleby, the Scrivener," a tale about an apparently deeply depressed man who, it transpires, may have been prompted into his "pallid hopelessness" through excessive exposure to thousands of undelivered letters while employed at the Washington Dead Letter Office (Bartleby 34). Powers' first person narrative jumps back and forth between the protagonist's home in the hinterlands surrounding Richmond, Virginia, and the backcountry surrounding a small, semi-fictional town called "Al Tafar" in Nineveh Province, Iraq. (The name "Al Tafar" - as opposed to the actual town of Tal Afar is a clear attempt on Powers' part to create a degree of distance between Bartle's experiences in Iraq and his own. It is a subtle but important distinction that reviews of the novel, which have tended to place a heavy emphasis on its verisimilitude, have occasionally overlooked. $)^{2}$

When John and his cynical Sergeant, Sterling, find Murph's mutilated body, they decide that the most honourable thing to do is to dispose of it, rather than allow it to be formally sent back to the US, where it would be shown to Murph's mother for identification 
(in another possible "Bartleby" reference, John also writes a reassuring letter to Murph's mother in her son's guise: a grimly literal take on the notion of the "dead letter"). Bartle and Sterling take the corpse deep into the Nineveh wilderness and deposit it in the Tigris. This is the event that the entire novel has been building toward, but is mirrored earlier on in the book when John, back home in Virginia, takes a walk into the countryside surrounding the James River. "Back home," John narrates, "everything had begun to remind me of something else," and this comes to a head as he sits by the river (134). He tries unsuccessfully to "reconstruct" Murph in his mind, but finds that the memory of his friend is a kind of "misguided archaeology": the closer he gets to remembering, he says, "the more the picture [he is] trying to re-create [recedes]" (134). Although he takes comfort in the openness of the countryside, enjoying the feeling of being "hardly a speck on the landscape," it also wracks him with guilt. So overwhelming is his sense of culpability that he recedes into a two-page stream of consciousness that culminates in him unconsciously submerging himself in the river, where he almost drowns.

Like the desert in Gods Without Men, the hinterlands surrounding the James River has formed an intimate connection, at least for John, with that surrounding the Tigris. The rivers are doubly metaphorical in this sense, as their water is literally connected by the world's oceans: any attempt to separate Virginia and Nineveh Province into completely separate "worlds" is, the novel implies, itself an exercise in "misguided archaeology." As John says elsewhere: "Nothing is more isolating than having a particular history. At least that's what I thought. Now I know: All pain is the same. Only the details are different" (132). However, the sentiment of this statement is invested with a bitter irony through a cold and brutal act of violence that takes place during the scene of Murph's burial. The lead-up to the burial, from the discovery of Murph's body to it being laid to rest in the river, takes up approximately seven pages, in which John and Sterling take the corpse on a long, emotionally draining walk 
along the river until they are far enough from town to safely dump it. All the while, they have a local hermit with them to push the body along in a cart. The hermit is never referred to by name, and is a quiet presence in the background as the two Americans preoccupy themselves with Murph's tragic death. Then, at the very end of the scene, once they have disposed of the body, John narrates as follows: "I looked at the ground. The dust blowing in fine swirls around my boots. I knew what was coming. Sterling shot the Cartwright once, in the face, and he crumpled to the ground. No time to even be surprised by it" (211).

In this scene, the entwining of American and Iraqi histories is made manifest in the most sinister of ways. Through an inversion of the process in Kunzru's novel of the American desert becoming briefly Iraqi, here it is the ancient Assyrian history of Iraq's Nineveh Plains that is momentarily transmogrified into a lawless frontier in the American Wild West. It is a stark take on Butler's "derealization of loss," using the trope of the wilderness to encourage empathic connections while at the same time demonstrating how, like any metaphor, it is equally susceptible to exploitation in the service of a colonial imaginary that is overly rigid in its delineation of the categories of self and other. The Yellow Birds is a novel of two lives lost in the wilderness, and of the sharp, absurd imbalance in the perceived value attributed to each. Like in the other novels, a "connective dissonance" occurs between the American wilderness and that of Iraq, and what results is the opening of an imaginative space in which new empathic "ties," of the kind that Butler calls for in Precarious Life, might begin to be emerge (40). 


\section{Absence and "Grievability"}

In America, Jean Baudrillard writes that US deserts are so fascinating "because you are delivered from all depth there - a brilliant, mobile, superficial neutrality, a challenge to meaning and profundity, a challenge to nature and culture, an outer hyperspace, with no origin, no reference-points" (133). He is, of course, only half-right: the absence of reference points in the American desert is itself an easily recognizable reference point, not least to anyone who has grown up with the Westerns, road movies and science fiction blockbusters of twentieth century Hollywood cinema. Baudrillard himself cannot help but describe the desert's "barely perceptible evaporation of meaning" in terms that keep it inherently linked to the culture to which it supposedly offers an alternative: "The grandeur of deserts derives from their being, in their aridity, the negative of the earth's surface and of our civilized humours"; "Here the terms of desire are turned upside down every day, and the night annihilates them" (6-9). The desert is no more nor less absent of meaning, necessarily, than the nation's more urban environments: its topological "emptiness" merely provides a suitable metaphorical counterpoint to the perceived "sign pollution" of contemporary urban life (see e.g. Slocombe, 493-508).

In this section, I argue that this paradoxical process of signifying the absence of signification plays a key role in the novels' ability to engender a sense of "connective dissonance" through the wilderness trope. Like Baudrillard's desert, the wildernesses described in the novels at hand provide a "negative," or "upside down," version of society's "civilized humours," but they do so in a way that foregrounds the unstable foundations upon which such civilized humours are constructed. In other words, the novels draw attention to the fact that the apparent absence of humanity in the wilderness is itself merely an expression of humanity. In their manipulation of the terrain's “imaginative geography," they use the 
absence with which the landscape is culturally associated as a device through which to highlight a similar absence common to Western representations of the war: specifically, the absence of what Butler might describe as recognizably "grievable" Iraqi lives (13-15).

\section{The Absence of Iraq}

Spatial absence - namely, that of physical things, people or places - is the most immediately ostensible way in which absence figures in the three texts, and is particularly apparent in Point Omega's extended comparison between the construction of absence in the desert and that in the Iraq war. "I'll tell you this much," Elster says to the narrator, Jim, at one point during filming,

"War creates a closed world and not only for those in combat but for the plotters, the strategists. Except their war is acronyms, projections, contingencies, methodologies. ... They become paralyzed by the systems at their disposal. Their war is abstract. They think they're sending an army into a place on a map." (28)

Baudrillard's argument that the first Gulf War "Did Not Take Place" is clearly evoked in this passage, but I would be careful about suggesting that DeLillo - whose novels once provided a fictional supplement of sorts to Baudrillard's work on postmodern simulacra - necessarily endorses this view as it is expounded by Elster here. Elster is presented as a figure whose thinking remains rooted in the late twentieth century: as is clear from the prevalence of digital communications technology during the second Iraq war, as well as from the fictional representations of loss in the wilderness discussed in the previous section, his ridiculing of the notion that United States military strategists "think they're sending an army into a place on a map" is not entirely convincing. As I have already indicated, what the three novels are concerned with is not so much the unreality of the war's "mapping," but rather the ways in 
which this mapping might be manipulated both for and against reactionary hegemonic power. It is not the inauthenticity of such simulacral mapping in itself that is conducive to the kind of "closing of worlds" that Elster describes, but rather the deliberate shaping of the map in a way which produces a "derealization of loss."

James Lasdun has noted that the novel is "as interesting for what it omits as what it includes," and, despite some allusion to the lead-up to the 2003 invasion early in the narrative, Iraq remains an absence throughout (n. pag.). However, such is the conspicuousness of its absence that it might be described as "present" in its very absence (once again in a way that gestures toward a kind of "connective dissonance" between the United States and Iraq). The haunting "presence" of Iraq's absence is particularly apparent in a scene late on the book, when, after Elster's daughter has been missing for some time, a knife is found lying in a nearby ravine. The territory in which the ravine is located is known as the "Impact Area": it is "a former bombing range littered with unexploded shells," and entry is "prohibited" (91). The connotations that the abandoned military facility throws up immediately connect the possibly violent loss of Elster's daughter to the thousands of losses that have been experienced elsewhere during the war on terror.

This is not to suggest that DeLillo is engaging in political grandstanding or taking any sort of clear-cut position on the ethics of the Iraq invasion: to combat a "derealization" of the loss of hundreds of thousands of Iraqi lives is not necessarily to take an anti-war stand, but could equally be viewed as an urgent call for more responsible handling of the intervention. Either way, the point here is that the apparent attempt to undercut a Western "derealization of loss" in Point Omega goes beyond the question of the war's moral or legal legitimacy, instead addressing an a priori need for all political sides to refrain from perpetuating an overly rigid binary between the largely arbitrary categories of "us" and "them." It is this "disarticulation we hear in the term 'Us and Them"” which, to continue the line of reasoning 
that DeLillo has previously set up in his frequently-cited essay "In the Ruins of the Future," leads to Iraqi experience being "constructed" as an "absence" in the first place: the overly strict "othering" of the nation by commentators from all political perspectives leads to a reduction of its collective identity to a vague and essentialized facade of "difference" (n. pag.).

\section{"The Whole Scorched World": Narrowing Worldviews}

The "connective dissonance" that is generated through the geography of the Impact Area is, rather like the simulated Iraqi town in Kunzru's novel, done so through the way in which it jars with the notion of the wilderness being a place "untrammelled by man," where human life is absent. This is evident in the way that the area is described using a string of claustrophobic words and phrases, which undercut the indistinguishable "vast emptiness" that otherwise characterizes the desert surrounding Elster's house. Most obviously, the site is depicted as "a large swathe of geometry with squared-off borders," a description that evokes what one might view as a forceful attempt by humans to colonize the vast wilderness of the terrain, dividing it into unnatural shapes which offer a quite literal take on Elster's notion of a "closed" wartime world. However, this is followed by numerous other descriptions of the area's "closedness" that might be described as more "naturally" occurring. When Jim drives out to investigate the area, he quickly finds "tall seamed cliff walls surrounding the car" before reaching "a vehicle dead end." He then has to squeeze through a "tight passage," and is struck by the oppressive feel of the sky, which is described as "confined" and "compressed," "stretched taut between cliff edges, it was narrowed and lowered, ... scale the rocks and you could touch it" (92). 
In this scene, Jim's earlier impression of the desert's anonymity ("somewhere south of nowhere in the Sonoran ... or maybe it was the Mojave"), is given a new degree of distinctiveness: while initially, to a newcomer, it manifested as a unitary embodiment of “absence," a closer, more zeroed-in focus reveals the countless distinct geological features that combine to constitute the illusion that there is anything inherently unitary about this expanse of land. The desert has no clear lines of demarcation, and any desire to attribute to it an absolute absence of signification is by necessity one that is itself constructed within - and projected onto the terrain through - human social discourse. (Readers familiar with the gothic tradition, to take one example, will likely find a wealth of signification in the imposing, starkly oppressive landscape described above).

The effect that this zeroing in on the desert's geographical detail has for a "derealization" of Iraqi loss, I argue, is that it destabilizes a central assumption about a concept (namely, the wilderness) that constitutes a key tenet of traditionalist understandings of American identity. By rendering the concept of the American desert newly strange, DeLillo challenges the surety of this version of the American self, and, in doing so, by extension undercuts assumptions about the absolute strangeness of the non-American other. (The nationality of this "other" remains, of course, unspecified, but the novel's frequent references to Iraq bring the notional Iraqi "other" most prominently to mind.) This connection between the constructed "absence" of the desert and the equally constructed "derealization" of Iraqi loss during the war is compounded through the location's very name. "Impact Area" clearly evokes a sense of traumatic loss, the wounding impact of an event completely outside of normal experience. Indeed, a few pages previously, Jim describes Elster's loss in similar terms (and using a kind of awkward syntactical expression that will be familiar to readers of traumatic narratives): "The impact, gathering from the first moment, hard to absorb" (79). 
Surveying the Impact Area from the vantage point of "a high rubble mound" (which itself evokes loss through destruction and death in its word usage), Jim describes what he sees before him as "the whole scorched world" (92). The "scorched world" has clear religious and particularly apocalyptic - connotations, while also hinting at the kind of "scorched earth" tactics controversially used by US forces in Iraq in both Gulf Wars (in particular, the "Highway of Death" incident in 1992, the much publicised "shock and awe" bombing campaign over Baghdad in 2003, and the retaliatory evisceration of Fallujah in 2004) (1657). ${ }^{3}$ What is more notable in the context of the present discussion, however, is the narrator's use here of the definite article: Jim does not describe " $a$ whole scorched world" lying before him, but rather "the whole scorched world." On one level, of course, this is merely a form of rhetorical metonymy, in which Jim expresses the traumatic “closing” of Elster's world (as well as his own, albeit to a lesser extent) by reducing their perception of "the world" to their immediate surroundings. However, through the associations evoked by the word "scorched," it again enacts a form of "connective dissonance" between a single loss in a landscape close to home and thousands of others in a distant part of the globe. In the Impact Area, the emotional space between the apparently separate "worlds" of the United States and Iraq is collapsed, and the perceived distance between the losses is rendered momentarily irrelevant.

This unity implied in the phrase "the scorched world" might also raise some questions about the limits of "connective dissonance." Critics such as Ruth Leys and E. Ann Kaplan have, in their respective critiques of trauma theory, asked at what point the "sharing" of traumatic loss might begin to lose its meaningfulness, detracting from the complex and often highly idiosyncratic differences that traumatic experience entails. Kaplan writes that "the main problem in trauma studies" is that it needs to "distinguish[] different domains within which people work or relate to trauma" (39). Leys, meanwhile, drawing on Walter Benn Michaels, has argued that for trauma theorists such as Cathy Caruth, "history is collapsed into 
memory by redescribing ... 'something we have never known as something we have forgotten"” (285). In DeLillo's phrase specifically, one might detect what Dominick LaCapra describes as a potentially dangerous conflation of absence with loss:

To blur the distinction between, or to conflate, absence and loss, may itself bear striking witness to the impact of trauma and the post-traumatic, which creates a state of disorientation, agitation, or even confusion and may induce a gripping response whose power and force of attraction can be compelling. The very conflation attests to the way one remains possessed or haunted by the past, whose ghosts and shrouds resist distinctions (such as that between absence and loss). (46)

One might argue that through its reliance on the constructed absence of the desert and of that of the loss of Iraqi life, the novel itself comes close to perpetuating such a conflation.

However, what is more important than this, I would suggest, is the way in which DeLillo whether intentionally or not - demonstrates just how fine the line can be between, on the one hand, an opening up of sensitivity toward loss experienced by those previously beyond one's empathic reach, and, on the other, a "haunting" by this loss, and particularly by one's perceived complicity in it. The question of how to avoid the latter is again shown to be one about the limits of the self.

Standing in the Impact Area, suddenly overcome by the presence of Jessie's absence, Jim is forced into an uncomfortable awareness of his ipseity:

I closed my eyes and listened. The silence was complete. I'd never felt a stillness such as this, never such an enveloping nothing. But such nothing that was, that spun around me, or she did, Jessie, warm to the touch. I don't know how long I stood there, every muscle in my body listening. Could I forget my name in this silence? I took my hand off the wall and put it to my face. I was sweating heavily and licked the moist stink off my fingers. I opened my eyes. I was still here, in the outside world. (94)

Jim is clearly haunted by the absence that has replaced Jessie in the moment of her loss, and the language he uses in reference to himself reflects this. There is a tension between a highly - perhaps overly - distinct conceptualization of the boundaries between his self and 
the "enveloping nothing" (which is compounded through the focus on his bodily physicality), and, in contrast, a simultaneous dissolving of them ("could I forget my name in this silence?"). I would suggest that it is not only through a conflation of absence with loss that Jim is paralyzed by his traumatic haunting, but also through an overlooking of the way in which her absence is a construction of his imagination: her "nothingness" cannot be "warm to the touch" because it would by necessity then cease to be "nothing."

\section{Topographical "Lifeworlds"}

A similar conflation of absence with loss is enacted in the desert in Gods Without Men. The novel offers a geography that is highly reflexive, taking the "absence" that is deeply associated with the American desert and foregrounding its constructed nature by filling it with stories of loss. As Gregory writes in Geographical Imaginations:

reflexivity is an inescapable moment in any human geography; ... it is vital to overcome that estrangement from people, places and landscapes that spatial science imposed upon the discipline; and that any critical human geography must attend to the ways in which meanings are spun around the topoi of different lifeworlds, threaded into social practices and woven into relations of power. (76)

Kunzru's novel enacts a "critical human geography" similar to that which Gregory describes, but with one key difference: instead of "attend[ing] to the ways in which meanings are spun around the topoi of different lifeworlds," it depicts a multiplicity of different "lifeworlds" located upon the same topography. While an identical desert landscape might connote anything from outlaws to road trips to alien abductions, depending upon the genre of the narrative within it appears, the desert in Kunzru's novel is both more and less diverse than this in its significations. 
For both the Americans and the Iraqis around her, there is a dissonance between the simulated village in the desert and the actuality of violence in Iraq, but there is nothing "connective" about it because - with a few exceptions - their refusal to meaningfully acknowledge Laila's loss helps perpetuate the overly rigid categories of self and other, or "us" and "them," to which Laila can never fully belong. The loss of her father and of her childhood home has been derealized by those around her in a way that does not so much make the loss disappear as cause it to produce, or make present, an almost palpable absence in its place. "She knew it would feel strange to be surrounded by soldiers," Kunzru writes,

\begin{abstract}
but since Uncle had moved them to the desert, she'd seen enough of them - hard-faced young men driving about in trucks, buying cases of beer at the supermarket - to be prepared. So she was ready for that part, but not for this, not to feel as if she were actually back in Iraq. She tried to make the picture cute, to add a soundtrack of passionate guitars and surround it with pretty bleeding hearts and flowers and color the scene in romantic black and white, but still Baba lay there, broken and dead. He'd been there all alone. He must have been so frightened. It was worse, somehow, because they'd never let her see him. That only made his ghost more powerful. (282-3)
\end{abstract}

Like the presence of Jessica's absence in Point Omega, the absence of Laila's lost father and home will continue to haunt her until she can find a way to come to terms with the fact that the home that she longs for no longer exists in the same way that it once did, and as such to replace the overbearing presence of its absence with an absence that is actually absent (or at least present in a subtler, less distracting way).

Moreover, Laila is the only major character whose narrative occupies only one chapter in the novel (although she does make a brief appearance in two others). Appearing two-thirds of the way through the text, the chapter's plot has only the most tangential connection to any of the other stories up until the very end, when Laila discovers the lost child, Raj (until this point, the only link between this narrative and any of the others is the fact that Laila happens to be a big fan of Nicky Capaldi, with whom she has had a star-struck passing encounter a little earlier on in the book). Not only does its "singling out" as the only 
self-contained narrative lend it an elevated sense of importance, but its surprise connection to the novel's central plotline (or at least the plotline that comes closest to being its "central" one) powerfully underscores the motif of intersecting heterogeneous worlds.

\section{"Like a tattered quilt of fallen stars": Weaving Meaning out of Absence}

The notion of breaking the world down into fragments is presented with greater foreboding in The Yellow Birds. By the time of Bartle's stream of consciousness in the James River, it has become clear that his sense of connection to humanity has begun to fragment. When overcome by guilt and mourning over Murph's death later on, he finally reaches the point at which he can declare: "My separation was complete" (61). While it would be simplistic to read too close a connection into Bartle's experience in Iraq with Powers' own, it is notable that Brian Castner, who took part in a joint interview with the author for Connecticut Public Radio, has written that "Powers said that he wrote fiction because he needed the space to first make sense of the war, and then put it down in a new way that provided separation between him and it" (n. pag.). This is a starkly different kind of separation, which creates a distance from the war and, presumably, brings a return to a sense human connectedness slightly closer. On such a scale, war and humanity are at opposite ends, and proximity to one implies a separation from the other.

Bartle's sense of separation, and the solitude that stems from it (that is, of lost souls wandering the earth absented from a shared humanity), is again underscored through the landscape. This is particularly apparent when he recalls another moment with Murph, in which the latter "pointed to the low hills around the city. Small fires had sprung up in the distance. A few city lights and the fires on the hillside burned like a tattered quilt of fallen stars. 'It's beautiful,' I whispered. I was not sure if anyone heard me, but I saw the others 
point their fingers off into the darkness" (84). The simile "like a tattered quilt of fallen stars" evokes a sense of disconnectedness on more than one level: a quilt (like a text) must necessarily be woven from two or more initially separate strands, while stars are nodal points in a larger system or cosmos. However, there is also a subtle poetic tension in the phrase: while the joining together of strands in a quilt is literal, in a cosmos it is largely theoretical. Like time or temporality, the organization of stars and planets into systems provides a means of helping make sense of vast astrological phenomena that remain for the most part beyond the understanding of even the most advanced scientific minds.

The fragmentation of Bartle's identity evidences a similar tension. The violence and killing around him, which he says has become "normal," has shattered any subscription that he may have once held to the concept of an inherently shared humanity: like both a tattered quilt and a collection of fallen stars, humanity has, for him, been exposed as mere artifice, reduced once again to its constituent parts. The question with which he goes on to grapple is broader than that of whether an a priori shared humanity exists: more importantly, Bartle profoundly struggles with the question of whether, assuming that shared humanity is a fiction, it is a fiction worth adhering to and perpetuating. (In an interview with the Guardian, Powers has said that one of his purposes in the novel is to ask why "the stories we tell ourselves are always about our goodness and or idealism," and I would suggest that this sense of a shared humanity is precisely such a story. [n. pag.]) Even after declaring the "complet[ion]" of his separation from the human sphere, when he has been placed in a military jail to await trial for the disappearance of Murph's body, he continues trying to make sense of the war by drawing connections between the numerous horrific events that have constituted his experience of it: "My first few months inside," he narrates, "I spent a lot of time trying to piece the war into a pattern. I developed the habit of making a mark on my cell wall when I remembered a particular event, thinking that at some later date I could refer to it and assemble all the marks 
into a story that made sense" (216). However, on the next page, he concedes: "Eventually, I realized that the marks could not be assembled into any kind of pattern. They were fixed in place. Connecting them would be wrong. They fell where they had fallen. ... I eventually accepted the fact that the only equality that lasts is the fact that everything falls away from everything else" (217). Once again, like a "tattered quilt of fallen stars" on the horizon, the connective meaning that he has attempted to attribute to the marks on his wall "falls away," and they are drained of signification.

The problem for Bartle, which he never manages to fully understand, is not so much one of accepting the fictionality of shared human identity (his decision to break down the world's deserts and plains into "parcels" is, after all, also a way of fictionalizing the reality around him). Rather, it is that he makes a mistake similar to Baudrillard by overlooking the fact that an apparent "evaporation of meaning" does not necessarily equate to an absence of meaning, or at least not an absence that is completely without presence. Once again sparked by the hinterlands of Richmond's suburbs, Bartle at one point narrates: "I turned towards the line of trees across the river and saw the whole world in fractions of seconds like the imperceptible flicker of light between frames of film, the long unrecorded moments that made up my life, one after another, like a movie I never realized had been playing all along" (189). The volume, complexity and even sublimity of his traumatic experience during the war is too much for his imagination to even begin to comprehend, rushing through his memory in a way that confounds his capacity for understanding (this confounding is evident even in the form that the memories take: the reduction of a whole lifetime of experience into a split second, "the imperceptible flicker of light between frames of film").

It is in moments such as these that a kind of "meaningful" absence might be useful, standing in for such torrents of traumatic memory in a way that may help Bartle to progress with his life, but that does not allow the trauma to linger unacknowledged (as in the case of 
Melville's Bartleby). Moreover, such an absence may connect the loss of American life to that of Iraqi life, not only though a sharing of similarities but through a sharing of differences: that is, through an acknowledgement of the multitudinous differences within national and cultural identity groups as opposed to simply between them. Like in Gods Without Men and Point Omega, his acknowledgement may once again be referred to as a "connective dissonance," as it enables the author to explore the delicate question of how to open new empathic connections in a way that avoids homogenizing the potential incommensurability of different traumatic experiences.

\section{Acknowledgements}

This article emerged from a conference paper given at the "Iraq War Culture" conference organized by Dr Joseph Brooker at the Centre for Contemporary Literature, Birkbeck, University of London (1 March 2013).

\section{Notes}

${ }^{1}$ Drawing on an essay by Robert Stam, Gregory suggests in Geographical Imaginations that “[ $t$ ]he media constructed ... 'a fictive We' - interpellated into an imaginary community - whose vantage point was carefully established to both privilege and protect the (American) viewer through the fabrication of ('Allied') innocence and the demonization of the (Iraqi) enemy" (204).

${ }^{2}$ For an example of one such review, see: John Burnside, "The Yellow Birds by Kevin Powers - Review," Guardian, 31 August $2012<$ http://www.theguardian.com/books/2012/aug/theyellow-birds-kevin-powers-review> Although possibly a Guardian editorial slip, Burnside's otherwise perspicacious article contains the sentence: "Like his narrator, Kevin Powers was a soldier in Iraq for two years, serving in Mosul and Tal Afar."

${ }^{3}$ For "shock and awe" campaign and attack on Fallujah, see: "Iraq Profile: Timeline," $B B C$ News, section Middle East, last updated 23 July 2013 <http://www.bbc.co.uk/news/world-middleeast-14546763>; for "Highway of Death," see: Gregory, The Colonial Present, pp. 165-7.

\section{Works cited}

Balzac, Honoré de, "A Passion in the Desert," anonymous translation, Tales of the Napoleonic Era: 2 - An Historical Mystery, Farewell, A Second Home, Colonel Chabert and Three Short Stories (London: Leonaur, 2010) 
Banville, John, “Against the North Wall,” New York Review of Books, 8 April 2010 $<$ http://www.nybooks.com/articles/archives/2010/apr/08/against-the-northwall/?pagination=false $>$

Baudrillard, Jean, America (London: Verso, 2010)

_—_, The Gulf War Did Not Take Place (Bloomington: Indiana University Press, 1995)

Burnside, John, “The Yellow Birds by Kevin Powers - Review," Guardian, 31 August 2012 <http://www.theguardian.com/books/2012/aug/the-yellow-birds-kevin-powers-review>

Butler, Judith, Precarious Life: The Powers of Mourning and Violence (London: Verso, 2006)

\section{_- - Frames of War: When is Life Grievable? (London: Verso, 2009)}

Castner, Brian, “"The Yellow Birds': A Heartbreaking Story of Fighting in Iraq - and Then Coming Home," Foreign Policy, 12 October 2012

<http://ricks.foreignpolicy.com/posts/2012/10/12/the_yellow_birds_a_heart_breaking_story_ of_fighting_in_iraq_and_then_coming_home>

DeLillo, Don, "In the Ruins of the Future," Guardian, 22 December 2001

—_, Point Omega (Basingstoke and Oxford: Picador, 2010)

Gray, Richard, After the Fall: American Literature Since 9/11 (Oxford: Blackwell, 2011)

Gregory, Derek, Geographical Imaginations (Cambridge, MA, and Oxford: Blackwell, 1994)

_- , The Colonial Present: Afghanistan, Palestine, Iraq (Oxford: Blackwell, 2004)

"Iraq Profile: Timeline,” BBC News, section Middle East, last updated 23 July 2013 <http://www.bbc.co.uk/news/world-middle-east-14546763>

Kaplan, E. Ann, Trauma Culture: The Politics of Terror and Loss in Media and Literature (New Brunswick, New Jersey, and London: Rutgers University Press, 2005)

Khalidi, Walid, ed., All That Remains: The Palestinian Villages Occupied and Depopulated by Israel in 1948 (Washington, DC: Instituted for Palestine Studies, 1992)

Kumar, Amitava, "Hari Kunzru on Gods Without Men,” Paris Review, 6 March 2012 $<$ http://www.theparisreview.org/blog/2012/03/06/hari-kunzru-on-\%E2\%80\%98gods-withoutmen $\%$ E2\%80\%99/>

Kunzru, Hari, Gods Without Men (London: Penguin, 2012)

LaCapra, Dominick, Writing History, Writing Trauma (Baltimore: Johns Hopkins University Press)

Lasdun, James, "Point Omega by Don DeLillo," Guardian, section Books, 27 February 2010 <http://www.theguardian.com/books/2010/feb/27/don-delillo-point-omega> 
Lewis, Michael, “American Wilderness," in American Wilderness: A New History, ed. by Michael Lewis (Oxford and New York: Oxford University Press, 2007)

Lewis, Tim, "Kevin Powers: 'I've Always Had a Certain Level of Comfort with the Dark Part of the Human Experience,"” Guardian, 23 June 2013

<http://www.theguardian.com/books/2013/jun/23/kevin-powers-interview-yellow-birds>

Leys, Ruth, Trauma: A Genealogy (Chicago and London: University of Chicago Press, 2000)

Melville, Herman, "Bartleby, the Scrivener: A Story of Wall-Street," in Herman Melville, Bartleby and Benito Cereno (London and Mineola, NY: Dover, 1990)

Powers, Kevin, The Yellow Birds (London: Sceptre, 2012)

Slocombe, Will, "Littered with Meaning: The Problem of Sign Pollution in Postmodern, Poststructuralist and Ecocritical Thought," Textual Practice 19.4 (2005), pp. 493-508 